\title{
Effect of Integrated Nutrient Management on Garlic Yield, Nutrient Uptake and Pungency
}

\author{
A. Thangasamy* and K.E. Lawande \\ ICAR-Directorate of Onion and Garlic Research, Pune-410505, Maharashtra, India
}

\begin{abstract}
A field experiment was conducted to evaluate the effect of integrated nutrient management modules on garlic yield, nutrient uptake and pungency during 2011-12 and 2012-13. The experiment consisted of nine treatments with three replications in randomized block design. Application of inorganic fertilizer with Farm Yard Manure (FYM), Vermi Compost (VC) amd Poultry Manure (PM) increased garlic yield by 6.5-7.9 per cent compared to inorganic fertilizers alone and 9.9-11.2 per cent over single source of organic manure, biofertilizers, and inorganic fertilizers. Pyruvic acid content was higher in the plots receiving integrated use of inorganic fertilizers and organic manures. Biofertilizers increased soil organic carbon and maintained soil fertility compared to pre-planting soil test values. INM treatments had higher levels of nutrient uptake than the treatments receiving inorganic fertilizers alone. The result indicated that the farmers could save 25 per cent inorganic fertilizers and organic manures by integrating inorganic fertilizers, FYM with VC or PM, or by integrating inorganic fertilizers, FYM, VC, and PM.
\end{abstract}

Keywords: Inorganic fertilizers, soil organic carbon, soil fertility status, organic manures, nutrient uptake

\section{Introduction}

Garlic is an important vegetable crop of India since ancient times. It is also used as spices and condiments with high nutritive and medicinal value. Garlic production in India increased by 104 per cent during last decade with the introduction of high yielding varieties, application of chemical fertilizers, intensive farming and bringing the non-traditional areas under cultivation but its productivity increased marginally during the same period. Application of chemical fertilizers has played a crucial role in replenishment of nutrients removed by crops and crop yield increase. However, continuous use of chemical fertilizers alone over the years resulted in loss of soil organic carbon and deteriorated soil health.

Soil organic matter is a key component that defines soil quality (Doran and Parkin 1994) which acts as a reservoir of plant nutrients and serves as a substrate for soil microorganisms (Dutta et al. 2003). Addition of organic manures is essential for restoring soil quality and sustaining garlic production. However, organic manure has a number of shortcomings including low nutrient content, slow decomposition and different nutrient compositions depending on its organic materials, compared to chemical fertilizers (Han et al. 2016). Several authors have reported that mixed use of chemical fertilizers and organic manures decreases the

*Corresponding author: (Email: astsamy@yahoo.co.in) 
damage caused by chemical fertilizers and increases yield, nutrient uptake and quality (Chand et al. 2006; Thangasamy and Lawande 2015; Han et al. 2016). Hence, integrated use of mineral fertilizers, organic manures and biofertilizers are essential to increase the garlic production and to sustain soil health.

Garlic crop requires about 100-120 kg N, 30-35 $\mathrm{kg} \mathrm{P}_{2} \mathrm{O}_{5}, 90-100 \mathrm{~kg} \mathrm{~K}_{2} \mathrm{O}$ and 35-40 $\mathrm{kg} \mathrm{S}$ to produce $10 \mathrm{t}$ of garlic (Ganeshamurthy et al. 2017). Current recommendations of garlic indicated that the farmers are applying inorganic fertilizers and organic manures in excess of the crop requirement. Further, the farmers are mainly depends on farm yard manure (FYM) as source of organic manures. Availability of FYM is getting decreased due to dwindling cattle population. Hence, there is a need to use alternate sources of organic manures and biofertilizers. In view of these issues, a field experiment was carried out to evaluate the eight integrated nutrient management modules involving three organic manures (alone and in combinations), chemical fertilizers and bio fertilizers on garlic yield, nutrient uptake and pungency.

\section{Materials and Methods}

The experiment was carried out during rabi 2011-12 and 2012-13 under All Indian Network Research Project on Onion and Garlic at ICARDirectorate of Onion and Garlic Research, Pune, Maharashtra $\left(18.32^{\circ} \mathrm{N} ; 73.51^{\circ} \mathrm{E}\right)$. Climatic condition of the experimental site is subtropical dry humid climate with mean annual precipitation of $821 \mathrm{~mm}$. Much of the precipitation received during south west monsoon (June-September). The soil of the experimental site was clay loam, Typic Haplustepts and had pH (1:2) 8.01, electrical conductivity $0.23 \mathrm{dSm}^{-1}$ and organic carbon $6.68 \mathrm{~g} \mathrm{~kg}^{-1}$ soil, available $\mathrm{N} 62.8 \mathrm{mg} \mathrm{kg}^{-1}$, available P 10.6 $\mathrm{mg} \mathrm{kg}{ }^{-1}$, available $\mathrm{K} 211.9 \mathrm{mg} \mathrm{kg}^{-1}$, available S $10.6 \mathrm{mg}$ $\mathrm{kg}^{-1}$, available Fe $1.64 \mathrm{mg} \mathrm{kg}^{-1}$, available $\mathrm{Zn} 0.54 \mathrm{mg}$ $\mathrm{kg}^{-1}$, available $\mathrm{Mn} 2.04 \mathrm{mg} \mathrm{kg}^{-1}$, available $\mathrm{Cu} 2.50 \mathrm{mg}$ $\mathrm{kg}^{-1}$.

The experiment had 9 treatments viz T1-100\% of recommended NPKS (100:50:50:50 kg NPKS ha ${ }^{-1}$ ) alone; T2- T1+20 t FYM ha ${ }^{-1}$; T3-75\% recommended NPKS+15 t FYM ha'; T4-75\% NPKS+7.5 t poultry manure (PM) ha ${ }^{-1}$; T5-75\% NPKS+7.5 t vermicompost (VC) ha ${ }^{-1}$, T6-75\% NPKS+7.5 t FYM+3.75t PM ha ${ }^{-1}$; T7$75 \%$ NPKS+7.5 t FYM+3.75t VC ha ${ }^{-1}$; $78-75 \%$ NPKS $3.75 \mathrm{t} \mathrm{PM}+3.75 \mathrm{t} \quad \mathrm{VC} \mathrm{ha}^{-1}$ and $\mathrm{T} 9-75 \% \mathrm{NPKS}+5 \mathrm{t}$ $\mathrm{FYM}+2.5 \mathrm{tPM}+2.5 \mathrm{tVC} \mathrm{ha}^{-1}$. Biofertilizers Azospirillum and phosphorus solubilizing bacteria@5 kgha ${ }^{-1}$ each were applied before planting to all nine treatments. The experiment was laid out in randomized block design with three replications. Nitrogen, phosphorus potassium and sulphur were applied as per treatments. Recommended dose of fertilizer for garlic was 100:50:50:50 kg NPKS $\mathrm{ha}^{-1}$. One third of nitrogen, full dose of organic manures and recommended $\mathrm{P}, \mathrm{K}$ and $\mathrm{S}$ were applied at the time of planting. Remaining two third of nitrogen was applied in two equal splits at 30 and 45 days after planting. Standard package of practices were followed to grow the crop. The crop was harvested at maturity during last week of March and yield was recorded.

At harvest, ten plant samples were randomly selected. These samples were processed, digested and analysed using standard procedures. Total $\mathrm{N}$ was analyzed using the micro kjeldhal method, $\mathrm{P}$ and $\mathrm{S}$ using a spectrophotometer, $\mathrm{K}$ using a flame photometer. Fe, $\mathrm{Mn}, \mathrm{Cu}$ and $\mathrm{Zn}$ were determined using an atomic absorption spectrophotometer (Jackson 1967). Nutrient uptake was calculated by multiplying nutrient concentration with dry matter yield. The post harvest soil samples from each plot $(0-15 \mathrm{~cm})$ were randomly collected and were analysed following standard procedures. Treatment wise ten fresh garlic bulbs were randomly collected from each field at the time of harvest. Fresh garlic bulbs were used for the determination of pyruvic acid. Pyruvic acid content was estimated using the dinitro phenyl hydrazine (DNPH) reagent method 15 days after harvest. (Schwimmer and Weston 1961)

Two years data were pooled and one-way analysis of variance was carried out using Statistical Analytical System (SAS) software version 9.3. Differences among treatment means were compared using the least significant difference method and significance was determined at a level of $\mathrm{P}<0.05 \%$. 


\section{Results and Discussion}

Garlic yield

The results showed that use of 75 per cent recommended NPKS along with organic manures increased garlic yield over 100\% NPKS $+20 \mathrm{t} \mathrm{ha}^{-1}$ (Table 1) but it was not significant. The highest garlic yield was recorded in treatments receiving $75 \% \mathrm{RDF}+7.5 \mathrm{t}$ FYM+3.5 t VC ha ${ }^{-1}$ (T7) followed by 75\% NPKS $+5 \mathrm{t}$ $\mathrm{FYM}+2.5 \mathrm{t} \mathrm{PM}+2.5 \mathrm{t} \mathrm{VC} \mathrm{ha}^{-1}$ and $75 \%$ NPKS $3.75 \mathrm{t}$ $\mathrm{PM}+3.75 \mathrm{t} \mathrm{VC} \mathrm{ha-}{ }^{-1}(\mathrm{~T} 8)$. Application of $75 \% \mathrm{NPKS}+7.5 \mathrm{t}$ poultry manure (PM) ha ${ }^{-1}$ (T4) and 75\% NPKS+7.5 t vermicompost (VC) ha ${ }^{-1}$ (T5) had the lowest garlic yield. The results indicated that combined application of inorganic fertilizers, two or more organic sources and biofertilizers (T7, T8 and T9) increased garlic yield by $6.5-7.9 \%$ compared to inorganic fertilizers alone (T1) and $9.9-11.2 \%$ compared to integrated use of single source of organic manure and inorganic fertilizers (T3, T4 and T5). Sachan et al. (2017) reported that integrated use of NPK $(75 \%)+$ FYM $\left(2.5 \mathrm{t} \mathrm{ha}^{-1}\right)+$ poultry manure $\left(2.5 \mathrm{tha}^{-1}\right)+$ vermicompost $\left(2.5 \mathrm{t} \mathrm{ha}^{-1}\right)$ increased okra yield and protein content compared to integrated use of recommended dose of fertilizers and single organic manure. Similar results were also reported by Thangasamy and Lawande (2015) in onion. This indicated that integration of two or more sources of organic manures with inorganic fertilizers could help in reducing 25 per cent inorganic fertilizer without affecting garlic yield

Table 1. Effect of nutrient management on garlic yield, bulb size and total storage losses

\begin{tabular}{|c|c|c|c|c|c|c|}
\hline Treatments & $\begin{array}{l}\text { AGB } \\
(\%)\end{array}$ & $\begin{array}{c}\text { BGB } \\
(\%)\end{array}$ & $\begin{array}{c}\text { CGB } \\
(\%)\end{array}$ & $\begin{array}{l}\text { MBY } \\
\left(\mathbf{t h a}^{-1}\right)\end{array}$ & $\begin{array}{c}\text { Unmarketable } \\
\text { garlic (\%) }\end{array}$ & $\begin{array}{c}\text { TBY } \\
\left(\mathbf{t ~ h a}^{-1}\right)\end{array}$ \\
\hline $\mathrm{T} 1$ & 30.5 & 30.4 & 33.8 & 5.96 & 5.5 & 6.30 \\
\hline $\mathrm{T} 2$ & 30.6 & 31.4 & 34.0 & 6.03 & 4.1 & 6.28 \\
\hline $\mathrm{T} 3$ & 27.1 & 37.1 & 31.7 & 6.02 & 4.2 & 6.28 \\
\hline $\mathrm{T} 4$ & 20.6 & 33.9 & 36.7 & 5.78 & 8.8 & 6.34 \\
\hline T5 & 23.5 & 32.9 & 37.9 & 5.78 & 5.8 & 6.13 \\
\hline T6 & 27.1 & 35.6 & 33.0 & 5.86 & 4.3 & 6.13 \\
\hline $\mathrm{T} 7$ & 28.2 & 32.8 & 34.7 & 6.43 & 4.4 & 6.72 \\
\hline $\mathrm{T} 8$ & 30.6 & 37.5 & 27.1 & 6.13 & 4.9 & 6.44 \\
\hline T9 & 33.1 & 31.0 & 31.4 & 6.35 & 4.7 & 6.66 \\
\hline $\operatorname{LSD}(p=0.05)$ & 11.5 & 13.7 & 8.1 & NS & NS & NS \\
\hline $\mathrm{CV} \%$ & 27.3 & 21.8 & 20.5 & 9.19 & 30.6 & 12.90 \\
\hline
\end{tabular}

*AGB- A grade bulb; *BGB- B grade bulb; *CGB- C grade bulb; MYB- Marketable bulb yield *TBY- Total bulb yield.

\section{Nutrient uptake}

The highest N, P, K, S and Zn uptake was observed in plots receiving 75 per cent inorganic fertilizers and two or more organic manures (T7. T8, T9) compared to remaining INM treatments (Table 2). However, no significant difference was observed between the treatments for N, P, K, S and Zn uptake. The highest nutrient uptake with application of inorganic fertilizers and organic manures could be due to addition of plant nutrients directly through organic manures and indirectly through solubilization of unavailable native nutrients and chelation of complex intermediate organic molecules produced during decomposition of added manures (Mitra et al. 2010). 
Table 2. Influence of inorganic fertilizers along with organic manures on macro and micro-nutrient uptake in garlic

\begin{tabular}{|c|c|c|c|c|c|c|c|c|}
\hline \multirow[t]{2}{*}{ Treatments } & \multicolumn{4}{|c|}{ Macronutrient uptake ( $\left.\mathrm{kg} \mathrm{ha}^{-1}\right)$} & \multicolumn{4}{|c|}{ Micronutrient uptake } \\
\hline & $\mathbf{N}$ & $\mathbf{P}$ & $\mathbf{K}$ & $\mathbf{S}$ & $\begin{array}{c}\mathrm{Fe} \\
\left(\mathrm{kg} \mathrm{ha}^{-1}\right)\end{array}$ & $\begin{array}{c}\mathrm{Zn} \\
\left(\mathrm{g} \mathrm{ha}^{-1}\right)\end{array}$ & $\begin{array}{c}\text { Mn } \\
\left(\mathrm{g} \mathrm{ha}^{-1}\right)\end{array}$ & $\begin{array}{c}\mathrm{Cu} \\
\left(\mathrm{g} \mathrm{ha}^{-1}\right)\end{array}$ \\
\hline $\mathrm{T} 1$ & 95.3 & 11.8 & 61.8 & 31.4 & 4.93 & 120.7 & 151.2 & 16.6 \\
\hline $\mathrm{T} 2$ & 97.0 & 12.4 & 61.7 & 32.0 & 5.23 & 132.1 & 164.0 & 16.5 \\
\hline $\mathrm{T} 3$ & 99.8 & 13.7 & 64.7 & 35.3 & 5.80 & 156.7 & 178.6 & 18.2 \\
\hline $\mathrm{T} 4$ & 95.2 & 12.6 & 62.3 & 32.4 & 5.24 & 137.9 & 138.3 & 17.9 \\
\hline $\mathrm{T} 5$ & 99.0 & 12.9 & 65.3 & 32.2 & 5.24 & 138.6 & 159.9 & 18.3 \\
\hline T6 & 94.3 & 12.2 & 62.3 & 30.4 & 4.84 & 131.3 & 151.0 & 16.3 \\
\hline $\mathrm{T} 7$ & 97.8 & 12.5 & 64.2 & 33.1 & 4.62 & 132.2 & 137.4 & 15.8 \\
\hline $\mathrm{T} 8$ & 99.9 & 12.9 & 66.9 & 36.0 & 4.97 & 138.7 & 131.4 & 15.7 \\
\hline T9 & 103.7 & 12.4 & 63.8 & 33.4 & 4.36 & 136.0 & 128.0 & 16.1 \\
\hline $\operatorname{LSD}(p=0.05)$ & NS & NS & NS & NS & 0.9 & NS & 29.1 & NS \\
\hline $\mathrm{CV} \%$ & 13.0 & 13.8 & 10.3 & 13.9 & 10.6 & 11.0 & 11.3 & 14.4 \\
\hline
\end{tabular}

Pyruvic acid

The pyruvic acid content is commonly used as a measure of pungency (Ianni et al. 2015). The results showed that fertilizer treatments significantly increased pyruvic acid content of garlic (Fig.1). The highest pyruvic acid content was recorded in the plot receiving 100\% NPKS+20 t FYM ha ${ }^{-1}$ followed by $100 \%$ NPKS alone and 75\% NPKS+7.5 t FYM+3.75t PM ha ${ }^{-1}$. This increase in pyruvic acid content in garlic bulbs could be due to higher dose of readily available inorganic sulphur compared to other treatments. Similar results were also observed by Thangasamy and Lawande (2015) in onion. The lowest pyruvic acid content was recorded where $75 \% \mathrm{RDF}+7.5 \mathrm{t}$ vermicompost $(\mathrm{VC})$ $\mathrm{ha}^{-1}$ (T5) and 75\% NPKS+7.5 t FYM+3.75 t VC ha was applied. This lower pyruvic acid in this treatment could be due to low sulphur supply from these organic sources and reduced application of inorganic sulphur (40 kg ha ${ }^{-1}$ ) as against $50 \mathrm{~kg} \mathrm{ha}^{-1}$ in $100 \%$ RDF. Previous studies have also showed that increasing the sulphur level increased the pyruvic acid content of onion bulbs (Qureshi and Lawande 2006; Thangasamy et al. 2013).

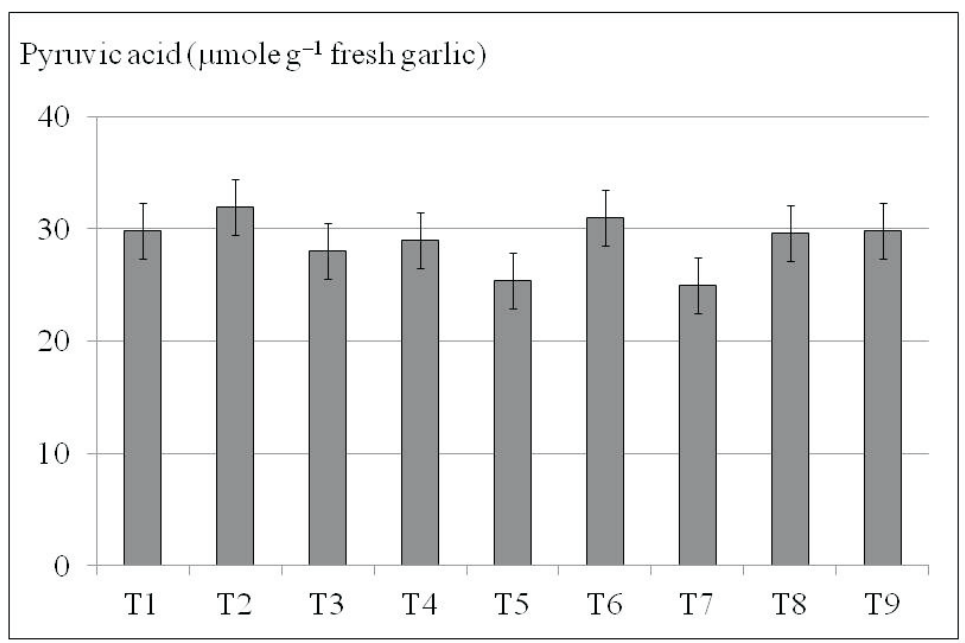

Fig.1. Effect of nutrient management on pyruvic acid content. Vertical bars represent one standard error of the mean $(n=27)$. 
Soil fertility status

At harvest, soil organic carbon increased than the initial value could be due to addition of organic matter through root exudates, root biomass addition and supply of readily decomposable organic matter (Goyal et al. 1999) Soil organic carbon varied between 7.1 and $8.0 \mathrm{~g} \mathrm{~kg}^{-1}$. (Table 3). Use of organic manures and inorganic fertilizers increased soil organic carbon compared to $100 \%$ RDF alone (T1). The highest soil organic carbon content was recorded, where, $75 \%$ NPKS 3.75t PM+3.75 t VC ha ${ }^{-1}$ was applied. The increase in soil organic carbon after the harvest in INM plots could be due to addition of organic manure. The lowest soil organic carbon content was recorded in the plot received $100 \%$ NPKS alone. Available nutrients after harvest did not vary significantly. Soil N, P, K and S after harvest was maintained in all the treatments.

Table 3. Effect of application of organic and inorganic fertilizers sources on properties of post harvest soil

\begin{tabular}{|c|c|c|c|c|c|c|c|}
\hline \multirow[b]{2}{*}{ Treatments } & \multirow{2}{*}{$\begin{array}{c}\text { Soil } \\
\text { pH }\end{array}$} & \multirow{2}{*}{$\begin{array}{c}E C \\
\left(d S ~ m^{-1}\right)\end{array}$} & \multirow{2}{*}{$\underset{\left(\mathrm{g} \mathrm{kg}^{-1}\right)}{\mathrm{SOC}}$} & \multicolumn{4}{|c|}{ Soil available nutrients $\left(\mathrm{kg} \mathrm{ha}^{-1}\right)$} \\
\hline & & & & $\mathbf{N}$ & $\mathbf{P}$ & $\mathbf{K}$ & $\mathbf{S}$ \\
\hline $\mathrm{T} 1$ & 8.07 & 0.23 & 7.2 & 71.7 & 11.1 & 200.0 & 6.55 \\
\hline $\mathrm{T} 2$ & 8.10 & 0.26 & 7.7 & 73.9 & 10.3 & 188.5 & 5.80 \\
\hline $\mathrm{T} 3$ & 8.16 & 0.23 & 7.5 & 75.7 & 8.8 & 217.7 & 5.18 \\
\hline $\mathrm{T} 4$ & 8.23 & 0.22 & 7.3 & 73.9 & 11.7 & 203.5 & 4.42 \\
\hline T5 & 8.20 & 0.24 & 7.9 & 73.5 & 10.3 & 209.3 & 5.35 \\
\hline T6 & 8.20 & 0.26 & 7.4 & 73.9 & 10.3 & 220.4 & 4.34 \\
\hline $\mathrm{T} 7$ & 8.07 & 0.23 & 7.5 & 72.1 & 9.9 & 212.8 & 4.42 \\
\hline $\mathrm{T} 8$ & 8.11 & 0.23 & 8.0 & 71.7 & 11.1 & 229.2 & 3.58 \\
\hline T9 & 8.06 & 0.23 & 7.8 & 72.1 & 10.6 & 228.8 & 5.13 \\
\hline $\operatorname{LSD}(p=0.05)$ & NS & 0.04 & 0.07 & 4.0 & 3.3 & 40.7 & 1.86 \\
\hline $\mathrm{CV} \%$ & 1.71 & 10.07 & 11.12 & 3 & 18.4 & 5.6 & 21.5 \\
\hline
\end{tabular}

\section{Conclusion}

Integrated use of 75\% RDF (75:40:40:40 kg NPKS ha ${ }^{-1}$ ), two or more organic manures and biofertilizers produced comparable garlic yield with integrated use of 100:50:50:50 kg NPKS + 20 t FYM $\mathrm{ha}^{-1}$, and 100:50:50:50 kg NPKS ha ${ }^{-1}$ alone. Combined application of organic manures and inorganic fertilizers improved soil organic carbon compared to initial value also maintained the initial soil available NPKS. With combined application 75\% RDF (75:40:40:40 kg NPKS $\left.\mathrm{ha}^{-1}\right)$, two or more organic manures and biofertilizers, the farmers could save 25 per cent inorganic fertilizers and organic manures.

\section{References}

Chand, S., Anwar, M. and Patra, D.D. (2006). Influence of long-term application of organic and inorganic fertilizer to build up soil fertility and nutrient uptake in mint-mustard cropping sequence. Communication in Soil Science and Plant Analysis 37, 63-76.

Doran, J. W., and Parkin, T. B. (1994). Defining and assessing soil quality. Defining Soil Quality for a Sustainable Environment. Doran J W, Coleman D.C., Bezdicek, D.F., and Stewart, B. A. (Eds).SSSA Inc., Madison, Wisconsin, USA.

Dutta, S., Pal, R., Chakeraborty, A., and Chakrabarti, K. (2003). Influence of integrated plant nutrient supply system on soil quality restoration in a red 
and laterite soil. Archives of Agronomy and Soil Science 49, 631-637.

Ganeshamurthy, A.N., Thangasamy, A. Mahajan, V., and Gupta, P.K. (2017). Soil fertility and crop nutrition in onion and garlic: deliniation, deficiencies and management of nutrients. ICARDirectorate of Onion and Garlic Research, Technical Bulletin No. 25, Rajgurunagar, Pune.

Goyal, S., Chander, K., Mundra, M.C., and Kapoor, K.K. (1999). Influence of inorganic fertilizers and organic amendments on soil organic matter and soil microbial properties under tropical conditions. Journal of Biology and Fertility 29, 196-200.

Han, S.H., and J.Y., Hwang, J., Kim, S.B., and Park, B.B. (2016). The effects of organic manure and chemical fertilizer on the growth and nutrient concentrations of yellow poplar (Liriodendron tulipifera Lin.) in a nursery system. Forest Science and Technology 12, 137-143.

Ianni, F., Marinozzi M., Scorzoni, S., Sardella, R. and Natalini, B. (2015). Quantitative evaluation of the pyruvic acid content in onion samples with a fully validated high-performance liquid chromatography method. International Journal of Food Properties 19, 752-759.

Jackson, M.L. (1967). 'Soil Chemical Analysis'. (Prentice Hall of Index Private Limited. New Delhi, India).
Mitra, S., Roy A., Saha, A.R., Mitra, D.N., Sinha, M.K., Mahapatra, B.S., and Saha S. (2010). Effect of integrated nutrient management on fibre yield, nutrient uptake and soil fertility in jute (Corchorus olitorius). Indian Journal of Agricultural Sciences 80, 801-804.

Qureshi, A.A., and Lawande, K.E. (2006). Response of onion (Allium cepa) to sulphur application for yield, quality and its storability in S-deficient soils. Indian Journal of Agricultural Science 76, 535-537.

Sachan, S., Singh, D., Kasera, S., Mishra, S.K., Tripathi, Y., Mishra, V., and Singh, R.K. (2017). Integrated Nutrient Management (INM) in okra (Abelmoschus esculentus (L.) Moench) for better growth and higher yield. Journal of Pharmacognosy and Phytochemistry 6, 18541856.

Schwimmer, S., and Weston, W.J. (1961). Enzymatic development of pyruvic acid in onion as a measure of pungency. Journal of Agricultural Food Chemistry 9, 301-304.

Thangasamy, A., and Lawande, K.E. (2015). Integrated nutrients management for sustainable onion production. Indian Journal of Horticulture 72, 347-352.

Thangasamy, A., Sankar V., and Lawande, K.E. (2013). Effect of sulphur nutrition on pungency and storage life of short day onion (Allium cepa). Indian Journal of Agricultural Sciences 83, 10861089.

Received: February,2018 Accepted: June, 2018 